\title{
Lead Groups in EU Foreign Policy: The Cases of Iran and Ukraine
}

\author{
Riccardo Alcaro \\ Research Coordinator and Head of the Global Actors Programme at the \\ Istituto Affari Internazionali (IAI), Rome, Italy \\ r.alcaro@iai.it \\ Marco Siddi \\ Senior Research Fellow at the Finnish Institute of International Affairs \\ (FIIA), Helsinki, Finland \\ marco.siddi@fiia.fi
}

\begin{abstract}
Since the creation of the EU, there have been instances in which a restricted number of member states has handled an issue of international security on behalf of the Union. This article argues that, while controversial, these 'lead groups' have been a valuable practice. They have been effective in generating intra-EU consensus on specific issues and spurring the EU into action, thereby enabling a European response in the context of conflict management and complex international negotiations. Lead groups are sub-optimal arrangements compensating for the in-built institutional shortcomings of unanimity-based decision-making in EU foreign policy. As such, they do not bring integration further. They have nonetheless shown significant potential in giving initiative and content to EU foreign policy. This is shown through the analysis of two case studies, the Anglo-Franco-German trio involved in Iran's nuclear issue and the Franco-German duo brokering a truce between Russia and Ukraine.
\end{abstract}

\section{Keywords}

EU foreign policy - differentiation - lead groups - directoire - Iran - Donbas 


\section{Introduction}

Differentiation, conceived of as 'any modality of integration or cooperation that allows states (members and non-members) and sub-state entities to work together in non-homogeneous, flexible ways etc.,' is an essential aspect of European Union (EU) policymaking.

Foreign policy stands out because differentiation in this domain has unfolded mostly along an informal pattern. While EU treaties provide for mechanisms of differentiation in the unanimity-ruled Common Foreign and Security Policy, including constructive abstention, enhanced cooperation or entrusting a group of member states with a specific task, they have almost never been used. Constructive abstention allows one or more member states not to commit to decisions engaging others, and for enhanced cooperation among a subset of countries. ${ }^{2}$ Articles 42.5 and 44 of the Treaty on the European Union envisage the possibility of the Council formally mandating a group of member states to carry out a task on behalf of the EU, which in theory should provide room for the kind of policy practice discussed here. However, these provisions have never been activated.

Instead, EU member states have engaged in a range of ad hoc formats, including regional groupings and ad hoc groups as well as flexible cooperation within international bodies. ${ }^{3}$ These informal formats have often been created in response to major international crises, when swift action is required. The E3/EU group on Iran's nuclear issue - including France, Germany, the United Kingdom (UK) and the High Representative (HR) for CFSP, a position the Lisbon Treaty merged with the Vice-President of the European Commission (HRVP) - and the Franco-German duo in the Normandy format on the Ukraine crisis are two prominent cases in point.

Scholars who have analysed the E3/EU and the Franco-German Normandy duo $^{4}$ treat them as instances of contact groups or 'minilateral' mechanisms

1 Lavenex and Križić, 'Conceptualising Differentiated Integration: Governance, Effectiveness and Legitimacy', p. 3 .

2 For an analysis, see Grevi et al., 'Differentiated Cooperation in European Foreign Policy: The Challenge of Coherence', pp. 5-7.

3 Grevi et al., op. cit.; Howorth, 'Differentiation in Security and Defence Policy'.

4 Harnisch, 'Minilateral Cooperation and Transatlantic Coalition-Building'; Alcaro, Europe and Iran's Nuclear Crisis. Lead Groups and EU Foreign Policy-Making; Wittke, 'The Minsk Agreements: More Than 'Scraps of Paper'?; Helwig, 'Germany in European Diplomacy: Minilateralism as a Tool for Leadership'; Åtland, 'Destined for deadlock? Russia, Ukraine, and the unfulfilled Minsk agreements'. 
(involving a restricted number of states) that allow for faster action thanks to informal procedures of consultation and decision-making. ${ }^{5}$

Contact groups involving EU member states have specific features that relate to the fact that the EU itself is an international actor. Member states that participate in a contact group often report to, discuss with and seek the endorsement of other member states and EU institutions. The latter sometimes play a role of their own in the group, as has been the case with the involvement of the HRVP in the nuclear talks with Iran. The participation of EU institutions makes such informal groups more acceptable to the other member states, yet it is not a condition for such groups to qualify as a specific EU foreign policy practice. Their defining element is the capacity to generate intra-EU consensus on a certain matter and give EU policy direction and content.

Informal groups are thus about intra-EU consensus-building and policy operationalisation. This means that groups such as the 'Iran E3' and the Franco-German Normandy duo, or any other instance of similar groupings, are not inherently conducive to deeper levels of supranationalisation. They are not meant to make the EU more integrated, but rather more responsive, cohesive and capable of foreign policy action. This is ultimately the reason behind our terminological choice: they are 'lead' groups rather than 'core' groups of more integrated EU member states. ${ }^{6}$ We assume EU lead groups to be an informal crisis management practice involving a limited number of member states supported by EU institutions, with the broad - often tacit and at times grudging consent of the other member states.

The capacity of initiative of individual member states plays an essential role in both the formation and the operation of lead groups, as the group's insiders often present the other EU member states with a fait accompli. Lead groups thus invariably imply an asymmetry in the relationship between the insiders and the outsiders, whereby they tend to generate intra-EU tensions and are often perceived as undue attempts by certain member states to call the shots for all others.

In spite of the scarce enthusiasm for the practice, the historical record shows that lead groups have formed and have been able to steer the EU into specific policy actions. The practice relies on an implicit bargain, whereby the outsiders agree to follow the lead group, which in turn gives them a degree of indirect representation and participation in the crisis management exercise.

The manner in which this happens varies on a case-by-case basis, yet there are some constants. The foreign policies of member states tend to be coordinated at the EU level and through EU institutional frameworks. This, together

5 Naim, 'Minilateralism: The Magic Number to Get Real International Action'.

6 Alcaro, op. cit., p. 6. 
with (in)direct involvement of EU institutions in lead groups, implies that lead groups have an important EU-level dimension. Delreux and Keukeleire ${ }^{7}$ as well as Alcaro ${ }^{8}$ argue that ad hoc or lead groups constitute the EU as a multi-actor system, in that they not only enable EU action on pre-existing goals but at times create an EU foreign policy where there had been none. ${ }^{9}$

The capacity of lead groups to give EU foreign policy direction and content ultimately draws from intra-EU consent, even if not explicitly formulated. Consent to the formation of the lead group, expressed indirectly through the support of the EU Council for the policy positions crafted and pursued by the lead group, is achieved through a mix of intergovernmental bargaining and adherence to common European values and identity.

EU lead groups can only emerge if both the group insiders and outsiders eventually have a greater stake in the group acting on behalf of, or in parallel to, the EU than otherwise. This bargain is only sustainable, however, if the lead group's policy course is in line with the EU identity layer of the member states outside the lead group. Conversely, 'no lead group can exist if it frames the crisis it addresses in terms that contradict the established EU [foreign policy] discourse.'10

We consider the two cases of the E3/EU Iran team and the Franco-German Normandy duo as especially illustrative for a number of reasons. One is that the $\mathrm{E}_{3} / \mathrm{EU}$ is a case where the lead group can indeed be said to have acted on behalf of the EU thanks to the direct participation of the HR (later HRVP) in the nuclear talks with Iran, while the Normandy duo is a case of a lead group working in parallel to EU institutions while at the same time orientating their action.

Another reason is the sheer geopolitical magnitude of Iran's nuclear plans and Russia's destabilisation of eastern Ukraine. Iran's nuclear programme has been a source of international concern since the early 200os, and Europe's involvement in it has consequently been the object of both policy-relevant and scholarly literature. ${ }^{11}$ The war in Ukraine has been one of the most serious European security crises since the end of the Cold War, ${ }^{12}$ but (unlike the $\mathrm{E}_{3} / \mathrm{EU}$

7 Delreux and Keukeleire, 'Informal Division of Labour in EU Foreign Policy-Making'.

8 Alcaro, op. cit.

9 This is not just an academic conclusion. The 2016 EU Global Strategy, which is the result of a two-year-long consultation process with all member states, has given lead groups a sort of formal sanction, in that it foresees the option of the HRVP tasking national foreign ministers to act on behalf of the EU (EEAs, EU Global Strategy. Shared Vision, Common Action: A Stronger Europe, p. 47).

$10 \quad$ Alcaro, op. cit., p. 49.

11 Ibid., pp. 4-5.

12 Averre and Wolczuk, 'Introduction: The Ukraine Crisis and Post-Post-Cold War Europe'; Haukkala, 'A Perfect Storm; Or What Went Wrong and What Went Right for the EU in Ukraine'; Kanet, 'Russian Strategic Culture, Domestic Politics and Cold War 2.o'; Siddi, 'German Foreign Policy towards Russia in the Aftermath of the Ukraine Crisis: A New Ostpolitik?.' 
Iran team) there are few analyses of the Franco-German duo in the Normandy format. Moreover, there is hardly any work that examines the formation and performance of lead groups based on two case studies.

In this article we address these gaps. Compared to earlier studies, ${ }^{13}$ the analysis of the $\mathrm{E}_{3} / \mathrm{EU}$ lead group on Iran also encompasses the period following the withdrawal of the United States (US) from the Iran nuclear deal, thereby expanding the empirical material from which we draw our generalisations and conclusions. As for the Normandy duo, we do not accept reductionist interpretations of it as a purely Franco-German endeavour, ${ }^{14}$ as the duo's position and actions have been intrinsically connected to, and have contributed to shaping, the policy course taken by the EU as such. In looking at these two cases, we have asked the following research questions: what were the conditions for their formation and endurance, and what their implications for EU foreign policy?

Three concepts are essential to explore these questions. First is the legitimacy of lead groups. Legitimacy should be traced back to both intra-EU conditions (bargaining capacity of the group's insiders and the normative compatibility of the group's policy with the EU's foreign policy discourse) and extra-EU conditions (external recognition, interlocution with key third players) for the formation of the lead group. ${ }^{15}$ Second is the sustainability of lead groups, notably their capacity to generate intra-EU consensus and solve internal conflicts. Finally comes the effectiveness of lead groups as a foreign policy practice that allows for the operationalisation of EU policy positions or the generation of a new policy.

The question of measuring effectiveness has generated considerable debate in EU foreign policy literature. According to an often-cited study, 'measuring effectiveness requires evidence of the situation or outcome that the EU has sought to influence, both before and after the EU adopted its position, and evidence that links change or stability in those conditions to the existence and/or efforts of the EU'. ${ }^{16}$ We expand on this conceptualisation and, following Lavenex and Križić, ${ }^{17}$ we assess effectiveness based on two benchmarks. The first benchmark is the relative improvement caused by lead groups compared to the state of affairs before they were established or to a hypothetical situation in which they had not been established. In other words, can any improvement or worsening in foreign policy outcomes be attributed to the presence of lead

\footnotetext{
13 Alcaro, op. cit.

14 Åtland, op. cit.

15 For an extensive discussion of internal/external legitimacy in EU foreign policy, see Sjursen, 'The legitimacy of European Union foreign policy'.

16 Thomas, 'Still Punching below Its Weight? Coherence and Effectiveness in European Union Foreign Policy', pp. 46o-461.

17 Lavenex and Križić, op. cit., pp. 10-11.
} 
groups? The second benchmark is the comparison of the policy achievements of lead groups with an optimal or ideal solution: does the policy impact of lead groups constitute an optimal solution of the underlying foreign policy issue, or is it insufficient to resolve it? ${ }^{18}$

\section{The E3/EU and Iran's Nuclear Programme}

Iran's nuclear programme has been an issue of international concern for two decades. While Iranian leaders have always stated that their country just seeks atomic energy for peaceful purposes, experts in the EU and elsewhere worry that Tehran could acquire the know-how and industrial capacity to build nuclear weapons.

Using a combination of diplomacy and sanctions, and following a twelveyear process sanctioned by the United Nations Security Council (UNSC), in July 2015 a coalition of six world powers - China, France, Germany, Russia, the UK and the United States - along with the EU, reached an agreement with Iran. The deal, officially known as the Joint Comprehensive Plan of Action (JCPOA), introduced a complex system of temporary limits to Iran's ability to carry out nuclear activities and gave the International Atomic Energy Agency (IAEA) expanded powers to conduct in situ inspections to verify the solely peaceful nature of the nuclear programme. In return, Iran got extensive sanctions relief from the US, the EU and the UN. ${ }^{19}$

The nuclear deal started to crumble after President Donald Trump (2017-2021) unilaterally ceased US compliance with it and re-adopted all sanctions in May 2018. In response, from May 2019 on Iran began to gradually cross the JCPOAset limits on its nuclear activities. ${ }^{20}$ In early 2021 Iran also decided to limit the access of IAEA inspectors to its nuclear facilities.

18 The empirical analysis in sections 2 and 3 draws on evidence gathered during semistructured interviews conducted with German, French and British officials during the autumn of 2020. The interviews targeted officials with first-hand knowledge of the nuclear negotiations with Iran and the Normandy format on Ukraine. All interviewees were involved directly in the preparation and conduct of the negotiations as representatives of the German, French and British foreign ministries and, in the case of the Normandy format, of the German Chancellery and the French Presidency of the Republic. A former Ukrainian highranking government official involved in the Normandy negotiations was also interviewed. Furthermore, we have drawn extensively on research findings acquired during our earlier work on negotiations concerning the Iranian nuclear programme and the Ukraine conflict.

19 E3/EU+3 and Iran, Joint Comprehensive Plan of Action; Fabius, 'Inside the Iran Deal: A French Perspective'; Fitzpatrick, 'Assessing the JCPOA'.

International Crisis Group, The Iran Nuclear Deal at Four: A Requiem?. 
However, the deal is formally still in place. The Europeans have continued to profess their commitment to it - as have China and Russia - and Iran has expressed readiness to bring its nuclear activities back in line with the JCPOA if the US returns to compliance. ${ }^{21}$ With Trump out of the White House, there is now a chance that that may happen, as President Joe Biden has been explicit about his intention to restart nuclear diplomacy with Iran. ${ }^{22}$ After some initial hesitations, in April 2021 Iran agreed to resume contacts with the E3/EU, Russia and China and to have the Europeans act as a go-between for communication with the US. While negotiations are still ongoing, the prospects for a reactivation of the JCPOA have brightened.

Throughout the process that led to the signing of the JCPOA, as well as the period that followed the US withdrawal, the Europeans played a secondary yet significant role. ${ }^{23}$ Diplomatic efforts began in 2003 with a tripartite initiative of the $E_{3}$, which in late 2004 were joined by the $\mathrm{HR}$ in the $\mathrm{E}_{3} / \mathrm{EU}_{3}$ lead group and in early 2006 by China, Russia and the US in an expanded $\mathrm{E}_{3} / \mathrm{EU}+3$ format. ${ }^{24}$ Even as the US became the central driver of negotiations under President Barack Obama (2009-17), the Europeans contributed to the process through the adoption of sanctions and the coordinating role of the HR (since 2009, the HRVP), who acted as the chief interlocutor of the Iranians on behalf of the $\mathrm{E}_{3}+3$ up to and during the negotiations over the nuclear deal. ${ }^{25}$

Following the US pull-out, the Europeans took centre stage again in the attempt to salvage the deal from total collapse. ${ }^{26}$ While unable to deliver on the economic benefits promised to Iran due to the deterrent effects on EU banks and companies of US extraterritorial sanctions (an attempt to protect EU banks and companies through an E3-established barter system largely failed), the E3/EU's efforts aimed to buy enough time to keep the formal structure of the deal afloat, in the hope that the US could change tack or, as it happened,

21 International Crisis Group, Iran: The U.S. Brings Maximum Pressure to the UN.

22 Biden, 'There's a Smarter Way to Be Tough on Iran'.

23 Adebahr, Europe and Iran: The Nuclear Deal and Beyond; Cronberg, 'No EU, No Iran Deal: The EU's Choice between Multilateralism and the Transatlantic Link'; Alcaro, op. cit., pp. 225-242.

24 The group is formally known as $\mathrm{E}_{3} / \mathrm{EU}+3$ in recognition of the European origin of the initiative, although the media and analysts (especially from the US) usually refer to it as the $\mathrm{P}_{5}+1$, because it includes all five permanent members of the Security Council plus Germany.

25 Bassiri Tabrizi and Kienzle, 'The High Representative and Directoires in European Foreign Policy: The Case of the Nuclear Negotiations with Iran'.

26 International Crisis Group, How Europe Can Save the Iran Nuclear Deal. 
president. Under Biden, the $\mathrm{E}_{3} / \mathrm{EU}$ have returned to their role as facilitators of US-Iranian diplomacy that they have played for almost twenty years. ${ }^{27}$

\section{The Conditions for the E3/EU's Formation and Endurance}

The E3/EU's capacity of action (and ultimately effectiveness, as discussed below) has been a function of the group's ability to engender an intra-EU convergence dynamic, whereby they have remained for over fifteen years the main conduit for EU-Iran interactions. A combination of external and internal factors has contributed to this.

Consider the external factors first. When, in 2004, the E3 sought the consent of other member states to offer Iran a trade agreement with the EU in return for nuclear concessions, they expected no significant resistance from their fellow EU partners. ${ }^{28}$ The E3 benefited from the fact that Iran had recognised them as viable interlocutors on the nuclear front - actually the only viable interlocutors, as by 2004 US President George W. Bush (2001-9) was still opposed to talks with Iran and the Security Council was reeling from the bitter split over the US-led invasion of Iraq. The $\mathrm{E}_{3}$ could credibly contend that making changes to the negotiation format would risk derailing the talks. ${ }^{29}$ The E3's position inside the EU was further strengthened sometime later, when China, Russia and the US joined their efforts and the Security Council gave its endorsement. ${ }^{30}$

Moving to the internal factors, the E3 were aware that they needed a greater buy-in from other EU member states as they increasingly framed the possible resolution of the nuclear dispute as a step towards normalisation of EU-Iran economic relations. While the other member states never warmed to the $\mathrm{E}_{3}$ calling the shots on Iran, they failed to make a credible case that altering the negotiating format, for instance by having the EU as such take it over or by expanding the group to other member states, would bring real added value. Eventually the association of HR Javier Solana (in office 1999-2009) with the negotiation team provided a workable middle-ground solution: the E3 would bring the added political weight of the EU to the nuclear talks while providing the other member states with a degree of indirect representation. ${ }^{31}$

The HR secured greater visibility for the EU in the talks, most notably because the US, Russia and China agreed to have HR Solana and his successors -

27 Alcaro, 'Europe's Defence of the Iran Nuclear Deal: Less than a Success, More than a Failure'.

28 Kile, 'Final Thoughts on Iran, the EU and the Limits of Conditionality'.

29 Alcaro, op. cit., pp. 103 and ff.

3о Ibid., pp. 171-172.

$31 \quad$ Ibid., pp. 172-174. 
Catherine Ashton (2009-2014), Federica Mogherini (2014-2019) and Josep Borrell (since 2019) - act as chief interlocutors of the Iranians on their behalf. ${ }^{32}$ The inclusion of the HR has been also important because it has provided more accountability of the lead group to the EU Council, which the HR is mandated to keep informed about progress. ${ }^{33}$

It should be noted, however, that information-sharing has not been as extensive as other member states would have liked, as the $\mathrm{E}_{3}$ have at times pushed for the HR to selectively pass on the pieces of information deemed necessary to bolster intra-EU consensus for their next move. One case in point is the $\mathrm{E}_{3} /$ EU's decision not to fully uncover the extent of the harsh sanctions included in the draft of UNSC resolution 1929 before it was formally adopted in June 2010, as the E3 did not want the text to become a matter of intra-EU debate. Another is the E3/EU's refusal to share with their fellow EU partners the text of an interim agreement that the $\mathrm{E}_{3} / \mathrm{EU}+3$ and Iran struck in November 2013. The E3/EU were concerned that some member states would seek the relaunch of trade with Iran before the finalisation of the JCPOA, which at the time was being negotiated. ${ }^{34}$

The E 3 /EU's endurance has not resulted from any delegation of tasks from the EU Council but from a continuous reassertion by the $\mathrm{E}_{3}$ of their intra-EU leadership on the Iran nuclear file. The three have used different tactics to win, or at times compel, consensus on their tactics, thus ensuring the sustainability of the group.

Privileged access to Iran has allowed the $E_{3} / E U$ to lay out an assessment of the measures needed to advance the negotiations, which other member states have found difficult to dispute. Building intra-EU coalitions has served the purpose of cornering member states willing to take steps on their own, such as when the Italian foreign minister felt compelled to cancel a planned visit to Iran in 2009 because it broke with a tacit consensus that all high-level interactions with Tehran should be left to the HR. ${ }^{35}$ By far the most important element used by the $\mathrm{E}_{3} / \mathrm{EU}$ to engender intra-EU cohesion, however, has been the transatlantic relationship. ${ }^{36}$ The $\mathrm{E}_{3} / \mathrm{EU}$ have channelled US desiderata into the EU to create consensus either for harsher measures, such as an oil embargo

32 Team interview with a British official involved in the E3/EU+3 negotiation with Iran, 17 November 2020.

33 Alcaro, op. cit., pp. 161-164.

34 Alcaro, 'Catherine Ashton's Delicate Balancing Act in Tehran'.

35 Dinmore, 'Italy Cancels Minister's Iran Visit'.

36 Alcaro, op. cit., pp. 182 and ff. 
enacted by the EU in 2012, or for resisting US moves that would risk derailing the talks (before 2015) or the JCPOA itself (after 2018).

At times, the E3/EU have opted for meeting the other member states halfway, for instance when they agreed to put further sanctions on hold in spring 2009 due to opposition by other member states. ${ }^{37}$ On other occasions, they preferred to act on their own and then invite other EU member states to join their efforts, such as when in early 2019 they drew up a special purpose vehicle for trade with Iran, ostensibly designed to protect against US sanctions, as an $\mathrm{E}_{3}$ rather than EU-wide endeavour (later on other six EU states joined the mechanism on a national basis). ${ }^{38}$

In still other circumstances the E3 manoeuvred to avoid an open clash with certain member states. Poland, for instance, in early 2019 agreed to co-host a US-sponsored conference that was widely perceived to be an anti-Iran event crafted by the Trump Administration to give legitimacy to its maximum pressure policy. In this case, the $\mathrm{E}_{3}$ opted for de-emphasising the anti-Iran bias of the conference. At the same time, they worked on a consensus EU text that would set out all of Europe's concerns about Iran's human rights records, regional activities and ballistic programme while expressing firm commitment by all EU member states (including Poland) to the JCPOA. ${ }^{39}$

Arguably more important for the group's legitimacy, and therefore its sustainability, was that the $\mathrm{E}_{3} / \mathrm{EU}$ consistently construed their diplomatic action within the contours of the established EU foreign and security policy discourse.

The E3/EU framed the problem posed by Iran's nuclear programme as one of non-compliance with international non-proliferation norms to which Iran itself had subscribed, whereby the focus was on Iran's behaviour rather than on its regime. Consequently, the $\mathrm{E}_{3} / \mathrm{EU}$ insisted on a consensual solution to the nuclear dispute sanctioned by the Security Council and monitored by international verification bodies such as the IAEA. Sanctions and diplomatic pressure were justified as lawful means to this end, enabled if not directly mandated by a string of UNSC resolutions (UNSCRS 1737, 1747, 1803 and 1929).

This normative framework reflected the emphasis on pre-emptive diplomacy and effective multilateralism that the 2003 European Security Strategy and the Strategy against the Spread of Weapons of Mass Destruction had constructed as main features of EU foreign and security policy. ${ }^{40}$ These normative

37 Dinmore et al., 'EU Trio Targets Tougher Iran Sanctions'.

38 Online interview with three $\mathrm{E}_{3}$ officials involved in or with direct knowledge of the $\mathrm{E}_{3} / \mathrm{EU}+3$ negotiation with Iran, 17, 18 and 19 November 2020.

39 Ibid.; European Council 2019.

40 Ahlström, 'The EU Strategy against the Proliferation of Weapons of Mass Destruction'. 
themes were later re-articulated, but not fundamentally changed, by the 2016 Global Strategy. In fact, the latter internalised the E3/EU experience in that it construed the Iran case as a precedent for the successful combination of EU and national assets in the pursuit of objectives set at the EU level. ${ }^{41}$

The sustainability of the $\mathrm{E}_{3} / \mathrm{EU}$ has ultimately depended on their ability to insert the diplomatic initiative towards Iran into the established EU foreign policy framework, as well as to trace their policy action back to this same framework throughout the whole process. Remarkably, this continued to be the case even as the UK was about to leave the EU (and then actually left it in early 2020). ${ }^{42}$ This continuity further attests that intra-EU support for the JCPOA revolved around the consistency of the $\mathrm{E}_{3} / \mathrm{EU}$ policy with an established normative framework rather than with the greater resources of the $\mathrm{E}_{3}$ (this said, Brexit does have the potential to impact the lead group practice, as discussed below). In these terms, the legitimacy and (to a lesser extent) accountability of the group have been mutually reinforcing dynamics that have sustained the E3's intra-EU leadership on the Iran nuclear dossier. But what about the effectiveness of the group?

\section{The Effectiveness of the E3/EU's Policy Action}

Shortly after the JCPOA was struck, HRVP Mogherini hailed it as a major diplomatic success for the EU.43 Such an emphatic celebration could have seemed off the mark, given that the $\mathrm{E}_{3} / \mathrm{EU}$ had played second fiddle to the US, especially after the Obama Administration engaged the Iranians in secret talks in Oman in 2012-13. Furthermore, European claims to success were disproven by the failure to protect EU lawful trade with Iran from US extraterritorial sanctions, of which the Trump Administration made extensive use.

Yet, hyperbole aside, HRVP Mogherini was not wrong: the signing of the JCPOA was indeed a major achievement for the EU, and the defence of it from Trump's maximum pressure campaign is, in retrospect, a not irrelevant feat. ${ }^{44}$ The point here is to define effectiveness not so much as the ability of the $\mathrm{E}_{3} /$ EU to solve the nuclear dispute, a task they lacked the power assets to fulfil. Instead, the E3/EU's performance should be assessed according to their ability to enable US-Iranian nuclear diplomacy. ${ }^{45}$

41 Alcaro, op. cit., pp. 117 and ff.

42 In the words of a British official knowledgeable about the E3/EU process, 'Brexit changed nothing' (online interview, 17 November 2020).

43 Mogherini, 'The Iran Agreement Is a Disaster for Isis'.

44 Alcaro, 'Europe's Defence of the Iran Nuclear Deal...'.

45 Online interview with a British and an $\mathrm{E}_{3}$ official involved in the $\mathrm{E}_{3} / \mathrm{EU}+3$ negotiation with Iran, 17 and 18 November 2020. 
Here the E3/EU score higher than is usually assumed. Initially, the E3/EU's action towards Iran was meant to build a firewall against a potential military escalation involving Iran and a hostile Bush Administration by de-emphasising the geopolitical core of the dispute and instead recasting it in normative terms with which Iran could relate. The E3/EU thereby created normative common ground for the Security Council, including the US, to adopt a 'dual track' approach that combined sanctions with diplomacy. When the US took the lead in the nuclear talks under Obama, the $\mathrm{E}_{3} / \mathrm{EU}$ contributed to both tracks, broadly aligning their sanctions regime with that of the US while keeping Iran engaged (especially through the offices of the HRVP) and defending Obama's diplomatic approach vis-à-vis opponents to the JCPOA in the US Congress. Under Trump, the E3/EU resorted to a strategy of damage limitation, whereby they gave Iran an incentive not to quit the deal altogether in the hope of a change of tack in Washington. Under the Biden Administration, the E3/EU's prospective role is that of injecting new life into the nuclear deal by restarting at least part of the trade with Tehran, thereby creating more conditions for renewed US-Iranian nuclear diplomacy. ${ }^{46}$

The fact that the E3/EU have continued to shape and direct EU foreign policy towards Iran even when results were disappointing warrants a nuanced appreciation of both the effectiveness of lead groups and effectiveness as a source of the lead group's legitimacy and sustainability. The E3/EU have not been able to solve the nuclear dispute with Iran but have managed to preserve a diplomatic space for a US-led resolution that would eventually serve EU normative and security interests. In these terms, it is possible to assume that effectiveness (as defined above) has also contributed to the sustainability of the $\mathrm{E}_{3} /$ $\mathrm{EU}$, although it has not been the primary source of it.

\section{The Franco-German Normandy Duo and the Donbas Conflict}

The Normandy framework is an international semi-formalised format for negotiations that supports a conflict settlement and transition process in Ukraine's eastern regions of Donetsk and Luhansk. Its name derives from the fact that it was established by the leaders of France, Germany, Russia and Ukraine during a meeting on the margins of the 7oth anniversary of 'D-Day' in June 2014. The Normandy format has since been the main diplomatic forum for the Ukraine conflict, on top of the 'Trilateral Contact Group' - including Ukraine, Russia,

46 Ibid. 
and the Organisation for Security and Cooperation in Europe (OSCE) - which was established at the initiative of the Swiss OSCE chairmanship in early June $2014 \cdot{ }^{47}$

The fact that the format came into being thanks to German and French diplomatic efforts, and that no EU official participates in the negotiations, points to the Normandy duo as being an exercise in intergovernmental diplomacy rather than EU foreign policy leadership. Indeed, French and German national diplomatic resources and authoritativeness in the eyes of the conflicting parties have been essential factors. However, as the following paragraphs elucidate, Franco-German diplomacy in the Normandy negotiations largely depends on being recognised, both internally and externally, as the legitimate expression of the European (if not Western) stance. Intra-EU support, or at least tacit consent, has been a critical aspect of the Franco-German lead group. Moreover, Germany and France have linked the implementation of the Minsk agreement, the main achievement of the Normandy negotiations, to the eventual lifting of sanctions against Russia, which are the cornerstone of the EU's policy in the Ukraine crisis.

It is also important to recall that the Normandy format was not the first effort by a group of EU member states to get involved in Ukraine's affairs. In February 2014, after months of mass street protests brought the government of the pro-Russian Ukrainian President Viktor Yanukovich to the brink of collapse, French, German and Polish representatives (the so-called Weimar triangle) attempted a mediation between protesters and the government. ${ }^{48}$ The agreement they brokered was however short-lived, as street protests continued and President Yanukovich abruptly left the country for Russia. The crisis immediately escalated, first in Crimea - which was quickly taken over by Russian security forces and then annexed after a referendum of dubious credibility and then in the Donbas, where Russian-backed separatists started an armed rebellion against the newly established pro-Western government in Kiev that continues to this day.

47 Åtland, op. cit., p. 13o. The Normandy format and the Trilateral Contact Group work in parallel. While the OSCE is not part of the Normandy format, its Special Representative on Ukraine, Swiss diplomat Heidi Tagliavini, was a member of the Trilateral Contact Group and participated in that capacity in the drawing up of the Minsk accords (Haug, "The Minsk Agreements and the osce Special Monitoring Mission. Providing Effective Monitoring for the Ceasefire Regime', p. 344). She also signed the Minsk I and II agreements on the OSCE's behalf, along with the representatives of Ukraine, Russia and the Donetsk and Lugansk separatist regions.

48 Yoder, 'Dialogues, Trialogues and Triangles: The Geometry of Germany's Foreign Policy of Trust-Building'. 
The EU's initial response, driven by Germany but with France toeing the line - consisted of a number of targeted sanctions against Russian individuals. Harsher sanctions on certain segments (defence, energy and finance) of Russia's economy followed in the summer, after a Malaysian Airlines aircraft was mistakenly shot down by Russian-backed separatists with Russianprovided ground-air weapons. At the same time, the EU continued to seek the off-ramp that Russia might take to de-escalate and eventually defuse the crisis. $^{49}$

From spring to summer 2014 German and French diplomacy supported an OSCE-led mediation effort within the Trilateral Contact Group, which led to the signing of the Minsk Protocol (or Minsk I) in September 2014. After the Minsk I ceasefire collapsed in the autumn, Germany and France stepped in to lead the negotiations, with German Chancellor Angela Merkel and French President François Hollande engaging in shuttle diplomacy between Moscow and Kiev. The process culminated in the Minsk II agreement, which brought down the level of violence while setting out the parameters for restoring Kiev's control of the Donbas. EU member states agreed that the removal of sanctions on sectors of Russia's economy would be tied to the implementation of Minsk II.

\section{The Conditions for the Normandy Duo's Formation and Endurance}

Neither HRVP Ashton nor her successor Mogherini were involved in the negotiations within the Normandy format. According to a French official, the HRVP was keen to play a more prominent role, but changing the format structure and adding a newcomer risked negatively affecting the working atmosphere in the negotiations. ${ }^{50}$ Nevertheless, scholars ${ }^{51}$ and practitioners ${ }^{52}$ maintain that the HRVP can promote EU foreign policy effectiveness by coordinating the use of supranational and national resources and by representing member states' consensus abroad.

The legitimacy of the Franco-German lead group mostly depended on its capacity to obtain recognition from the external players involved in the Ukraine crisis, whereby the other member states had no incentive to oppose

49 Helwig, 'Germany in European Diplomacy...'; Siddi, 'German Foreign Policy towards Russia in the Aftermath of the Ukraine Crisis...'; Siddi, 'A Contested Hegemon? Germany's Leadership in EU Relations with Russia.

Phone interview with French government official formerly working in the Normandy format, 13 November 2020 .

$51 \quad$ For example, Viceré, 'Looking towards the East: The High Representative's Role in EU Foreign Policy on Kosovo and Ukraine', pp. 345-347. 
the Franco-German push for linking their own mediation effort to the EU's sanctions policy. According to a German official, external recognition and interlocution with key third actors was essential to the formation and legitimacy of the lead group. Russia would only negotiate with 'European powers' and would not have accepted negotiations with EU officials. ${ }^{53}$ Russian officials preferred a restricted format such as Normandy over larger formats out of concern that the addition of more countries would result in the isolation of Moscow. ${ }^{54}$ Moreover, because HR Ashton had participated in street demonstrations in Kiev in December 2013 she was perceived as biased by Russian leaders. The fact that Berlin and Paris were on speaking terms with the Kremlin helped them be accepted as legitimate interlocutors. Conversely, when asked about the absence of the UK from the lead group on Ukraine, German and French diplomats mentioned the poor state of British-Russian relations as the main cause. ${ }^{55}$ Ukrainian leaders also trusted their German and French counterparts and accepted their leading role in the negotiations. ${ }^{56}$

Endorsement by the US was also important for the legitimacy of the FrancoGerman lead group. The Obama Administration put trust in the Franco-German duo, which remained in constant communication with the US. The regular flow of information continued until early 2017, when the newly inaugurated Trump Administration directed its attention elsewhere and let cooperation with Europe over Ukraine slip down in its list of priorities. Dwindling transatlantic coordination after 2017 weakened the idea that the West was acting in unison in the Ukraine crisis, but it had no clear effect on the Normandy negotiations..$^{57}$

External recognition gave the Franco-German lead group the political capital to generate intra-EU support for its mediation efforts. Even member states concerned that the lead group would give in too much to Russian requests, such as Poland, did not challenge the legitimacy of France and Germany to negotiate a peace agreement for the Donbas region and establish a link between the

53 Phone interview with a German government official who worked in the Normandy Four negotiations, 3 November 2020.

54 Phone interview with a French government official formerly working in the Normandy format, 13 November 2020 .

55 Phone interview with a German government official who worked in the Normandy Four negotiations, 3 November 2020; phone interview with a French government official formerly working in the Normandy format, 13 November 2020. Nonetheless, the UK played an important role in the negotiations leading to the imposition of EU sanctions on Russia.

56 Phone interview with a high-ranking Ukrainian government official involved in the Normandy Four negotiations, 3 December 2020.

57 Phone interview with a German government official who worked in the Normandy Four negotiations, 3 November 2020. 
negotiations and EU-wide action over the Ukraine crisis. ${ }^{58}$ Intra-EU consent was obtained through both the adoption of a policy line that was acceptable to all member states and intense information-sharing with them. The policy promoted by the lead group, combining sanctions with the continuation of dialogue and even substantial trade with Russia in some sectors (such as energy), ${ }^{59}$ satisfied those favouring a harsher line on Russia, like Poland, the Baltic states, Sweden and the UK, as well as those unwilling to jettison their relations with Moscow, such as Austria, Hungary or Italy.

The efforts of Merkel and Hollande to keep other member states informed of developments in the Normandy negotiations, both through EU channels and bilaterally, reassured them that Germany and France were acting in good faith and strengthened the sustainability of the lead group. National diplomats were apparently satisfied with the level of communication with the lead group. ${ }^{60}$

Occasionally, some member states advocated adjustments to the EU's policy line. In 2015 , for instance, Italy questioned the wisdom of automatically extending sanctions every six months and called for a review of restrictive measures. ${ }^{61}$ In 2016, then German foreign minister Frank-Walter Steinmeier advocated a flexible approach to sanctions, arguing that some could be lifted following even partial progress in the implementation of Minsk II. ${ }^{62}$ However, neither proposal went through. Italy was fairly isolated and never presented the other member states with an alternative mechanism for sanctions. Steinmeier's proposal was more specific content-wise, yet equally failed to garner support, and Germany did not press it so as to safeguard EU unity. Allegations of Russian electoral interference and support for right-wing parties in Europe, as well as Russia's bombing campaign in Syria, further weakened support for a more flexible stance. ${ }^{63}$

After the election of a right-wing government in Poland in late 2015, Polish officials began to criticise the Normandy format in media interviews, although the government did not formally challenge it. ${ }^{64}$ In spite of its participation

58 Cf. Natorski and Pomorska, 'Trust and Decision-making in Times of Crisis: The EU's Response to the Events in Ukraine', p. 64, Siddi, 'A Contested Hegemon?...' This was reiterated in our interview with the cited French government official formerly working in the Normandy format.

59 See Siddi, 'EU-Russia energy relations'.

6o Natorski and Pomorska, op. cit., p. 64.

61 Reuters, 'Italy PM Renzi Says Russian Sanctions to Be Reviewed in Coming Months'.

62 Reuters, 'Germany's Steinmeier Favors Gradual Phasing-Out of Russia Sanctions'.

63 Phone interview with a German government official who worked in the Normandy Four negotiations, 3 November 2020.

64 Sus, 'Poland: Leading Critic or Marginalised Hawk?', p. 82. 
in the Weimar triangle (see above) in February 2014, Poland did not find a way into any one of the negotiation formats that followed. One reason was surely Russia's unwillingness to negotiate with Poland, which was perceived as anti-Russian and lacking great-power prestige. Moreover, the Polish government's fiercely nationalistic and often anti-EU positions must have played a role in diminishing French and German appetite for bringing the Poles into the loop. The new Polish government did itself no favour with its at times inflammatory criticisms of Germany, such as Foreign Minister Witold Waszczykowski's claim that Germany and Russia had created a 'concert of powers over the head of Poland' ${ }^{65}$ In addition, Poland did not make any serious attempt to enter the Normandy negotiations before late 2016, when the group was sufficiently established for no party to see any advantage in changing its composition. ${ }^{6}$

The capacity of the Normandy duo to address and contain intra-EU criticism played an important role in ensuring its sustainability. Asked how the Franco-German lead group engaged with Poland's criticisms, German officials answered that they tried to compensate for Poland's absence from the negotiations by coordinating intensely with the Polish foreign ministry and prime minister's office. While this may have assuaged some of Poland's concerns, Warsaw was not able to make a constructive contribution either to the substance of the negotiations concerning the Donbas conflict or even to the EU's policy towards Ukraine, as Polish-Ukrainian relations became embroiled in historical disputes. ${ }^{67}$ Within the EU, Poland's criticism met with little or no concrete support among other national governments. Hence, Franco-German leadership in the Normandy negotiations was never really endangered.

The Franco-German duo paid close attention to making their actions in the Normandy format accountable to EU institutions. The German and French representatives closely prepared and coordinated before each Normandy meeting, spending hours on the phone each day. Merkel and Hollande reported extensively to European Council meetings on the progress of negotiations and gave their assessment of the way forward. German and French officials believed that they were 'acting on behalf of Europe'.68 Although EU diplomatic actors did not play a role in the Normandy format, the Franco-German lead

\footnotetext{
65 Cited in ibid., p. 82.

66 Unian, 'Polish Foreign Minister: Minsk Deal Not to Be Implemented, Normandy Format Must be Expanded'.

67 Cadier and Szulecki, 'Populism, Historical Discourse and Foreign Policy: The Case of Poland's Law and Justice Government'; Ibid.

68 Ibid.
} 
group needed the EU's institutions and networks for the internal coordination of European diplomacy, especially on sanctions. ${ }^{69}$

Moreover, the HR contributed to the implementation of EU foreign policy towards Ukraine based on the guidelines agreed upon by member states in the European Council. For instance, HR Mogherini catalysed the process leading to Ukraine's Association Agreement with the EU and supported RussianUkrainian-EU trilateral talks on gas transit and supply. According to Mogherini, 'these efforts were part of the concrete EU support to the implementation of the Minsk Agreements, ${ }^{\prime}{ }^{70}$ and were thus functional to the work of the FrancoGerman lead group. In February 2015, after the signing of the Minsk II agreement, the HRVP also proposed to the European Council 'concrete measures' that the EU could 'put in place to monitor and implement the agreement.71 However, subsequent Council conclusions did not mention these proposals, which suggests that even the HRVP's attempts to influence the Normandy negotiations had very limited success. ${ }^{72}$

\section{Effectiveness of the Normandy Duo}

In terms of effectiveness, the record of the Normandy duo is mixed. Once again, the Europeans have not been able to 'solve' the dispute: the Normandy format has not led to a resolution of the conflict in the Donbas. However, it has made the space for a 'weak but working' ceasefire. ${ }^{73}$ De-escalation was the short-term objective of the Franco-German duo. While this was largely achieved, Franco-German diplomacy was unable to stabilise the ceasefire and ensure full implementation of Minsk II. The unwillingness of conflicting parties to proceed with the deal's implementation surely bears the responsibility for this failure, rather than the Normandy format and Franco-German diplomacy. After all, even US mediation attempts produced no tangible results. The osce-led mediation in 2014 also failed to de-escalate the Donbas conflict. There is thus no evidence that other negotiation formats would have been more successful. ${ }^{74}$ Indeed, sustained de-escalation only occurred when, in February 2015, German and French leaders took centre stage in the negotiations and

69 Natorski and Pomorska, op. cit.

70 European Commission, Statement by Vice-President Šefčovič following the trilateral meeting EU-Ukraine-Russia on 2 March.

71 EEAS, Remarks by High Representative/Vice-President Federica Mogherini upon Arrival at the Informal Meeting of the Members of the European Council.

72 Cf. Viceré, op. cit., pp. 348-349.

73 Phone interview with a German government official who worked in the Normandy Four negotiations, 3 November 2020.

Ibid. 
conducted their shuttle diplomacy in Moscow, Kiev and Minsk. The main concrete attempts to solve the Donbas conflict have been based on proposals and deals negotiated by the Franco-German duo. The Minsk II agreement and the subsequent 'Steinmeier formula', which aimed to break the deadlock in the implementation of the agreement, provide apt examples. ${ }^{75}$

\section{Conclusions}

Lead groups come about because of the ability of individual member states to position themselves so that the other member states find it more advantageous to support rather than oppose their leadership in specific crisis management efforts. Usually this happens because the group insiders get external recognition from key third players, thus presenting the other member states with a fait accompli that is hard to contest publicly and even harder to reverse. The 'consent' to the insiders' leadership therefore comes, in most cases (including those analysed in this article), ex post rather than ex ante. This said, a lead group can only endure over time if it carries out a policy that reflects EU-wide strategic and normative interests. It is on this condition only that we can posit EU foreign policy as a multi-actor system that encompasses the action not just of EU institutions but also of the member states, and hence permits lead groups as a viable EU foreign policy practice.

Lead groups, whether they work on behalf of the EU or in parallel to EU institutions, are ultimately about creating consensus about a specific policy action and then implementing that action. The effectiveness of the action (even if defined in the less triumphalist terms mentioned above) may bolster, but does not ultimately explain, the sustainability of a lead group. The main achievement of the $\mathrm{E}_{3} / \mathrm{EU}$ and the Normandy duo, that of ensuring the EU's involvement in a crisis management exercise affecting EU normative and security interests, can hardly be described as a heroic exploit. However, it is worth underlining that in neither case would an action carried out by EU institutions and driven by the unanimity-voting Foreign Affairs Council have been realistic.

The question remains whether this practice dilutes EU foreign policy cohesion or, on the contrary, gives it direction and content. To an extent, it can be argued that the practice might work as a disincentive for EU member states, especially the larger ones that are more likely to be part of a lead group, to

75 The Steinmeier formula (first presented in 2016) called for the holding of free and fair elections in the separatist-held territories under OSCE supervision, after which these territories would be reintegrated in Ukraine with a special self-governing status. 
seek greater foreign policy integration, as lead groups give insiders both leeway to act on their own and access to EU assets. More broadly, lead groups, especially if the largest EU countries feature consistently among their members, surely contribute to protracting the never-abated concern about a directoire of large EU countries that call the shots for the others too - a concern that Brexit makes even more acute, as the UK sees an advantage in having a privileged platform of interaction with the EU's remaining big two, France and Germany.

These criticisms are not off the mark, although the empirical evidence is inconclusive. The notion that lead groups disincentivise further foreign policy integration hinges on an argumentative leap, as resistance to sovereignty transfer in the foreign policy area is rooted in political, institutional and domestic considerations affecting all EU member states, including the small ones. Concerns about a directoire may be more justified, especially with a post-Brexit UK pushing for keeping a position of influence in EU foreign policymaking through special ties with France and Germany. Yet it should be recalled again that even lead groups involving the largest member states - such as the two we discuss in this article - derive their sustainability from giving the EU, and therefore the other member states, a degree of representation and participation in the crisis management exercise. ${ }^{76}$

Lead groups offset the procedural and institutional shortcomings of the Common Foreign and Security Policy, and in that sense they are always sub-optimal arrangements. The degree to which they ensure participation of EU institutions varies - for instance, it is significant in the $E_{3} / E U$ Iran case due to the HRVP's association with the negotiation format, whereas it is non-existent in the Normandy duo. Yet the point is less about direct participation of EU institutions than it is about defending and pursuing collectively constructed normative and strategic interests. More detached lead groups, such as the Normandy duo, perform this function as much as lead groups to which EU institutions are a party, as is the case with the E3/EU Iran team.

In conclusion, insofar as they operationalise policy positions agreed at the EU level, or create a policy where there had been none, lead groups are a positive net for EU foreign policy and a practice whose potential for strengthening the EU's international profile is greater than the risk of fragmenting intra-EU cohesion.

${ }_{76}$ Online interview with a French official with direct knowledge of the E3/EU+3-Iran negotiations. 


\section{Bibliography}

Adebahr, Cornelius. Europe and Iran: The Nuclear Deal and Beyond (London: Routledge, 2017).

Ahlström, Christer. 'The EU Strategy against the Proliferation of Weapons of Mass Destruction'. In Europe and Iran. Perspectives on Non-Proliferation, ed. S. N. Kile (Oxford: oup, 2005), pp. 27-46.

Alcaro, Riccardo. 'Catherine Ashton's Delicate Balancing Act in Tehran', Markaz blog, Center for Middle East Policy, The Brookings Institution (14 March 2014).

Alcaro, Riccardo. Europe and Iran's Nuclear Crisis. Lead Groups and EU Foreign PolicyMaking (Cham: Springer/Palgrave Macmillan, 2018).

Alcaro, Riccardo. 'Europe's Defence of the Iran Nuclear Deal: Less than a Success, More than a Failure', The International Spectator, vol. 56, no. 1 (2021), pp. 55-72, www. tandfonline.com/doi/full/10.108o/o3932729.2021.1876861.

Averre, Derek and Kataryna Wolczuk. 'Introduction: The Ukraine Crisis and Post-PostCold War Europe', Europe-Asia Studies, vol. 68, no. 4 (2016), pp. 551-555.

Åtland, Kristian. 'Destined for deadlock? Russia, Ukraine, and the unfulfilled Minsk agreements', Post-Soviet Affairs, vol. 36, no. 2 (2020), pp. 122-139.

Bassiri Tabrizi, Aniseh and Benjamin Kienzle. 'The High Representative and Directoires in European Foreign Policy: The Case of the Nuclear Negotiations with Iran', European Security, vol. 29, no. 3 (2020), pp. 320-336.

Biden, Joe. 'There's a Smarter Way to Be Tough on Iran'. CNN, 13 September 2020.

Cadier, David and Kacper Szulecki. 'Populism, Historical Discourse and Foreign Policy: The Case of Poland's Law and Justice Government', International Politics, vol. 57 (2020), pp. 910-1011, https://link.springer.com/article/10.1057/s41311-02O-00252-6.

Cronberg, Tanja. 'No EU, No Iran Deal: The EU's Choice between Multilateralism and the Transatlantic Link', The Non-Proliferation Review, vol. 24, no. 3-4 (2017), pp. $243^{-259}$.

Delreux, Tom and Stephan Keukeleire. 'Informal Division of Labour in EU Foreign Policy-Making', Journal of European Public Policy, vol. 24, no. 10 (2017), pp. 1-20.

Dinmore, Guy. 'Italy Cancels Minister's Iran Visit'. Financial Times, 20 May 2009.

Dinmore, Guy, Najmeh Bozorgmehr and Alex Barker. 'EU Trio Targets Tougher Iran Sanctions'. Financial Times, 25 February 2009.

$\mathrm{E}_{3} / \mathrm{EU}+3$ and Iran. Joint Comprehensive Plan of Action, Vienna, 15 July 2015.

EEAS (European External Action Service). Remarks by High Representative/VicePresident Federica Mogherini upon Arrival at the Informal Meeting of the Members of the European Council, 12 February 2015, https://eeas.europa.eu/delegations/ ukraine/2755/remarks-by-highrepresentativevice-president-federica-mogheriniupon-arrival-at-the-informal-meetingof-the-members-of-the. 
EEAS (European External Action Service). EU Global Strategy. Shared Vision, Common Action: A Stronger Europe, June 2016, https://eeas.europa.eu/sites/eeas/files/eugs_ review_web_o.pdf.

European Commission. Statement by Vice-President Šefčovič following the trilateral meeting EU-Ukraine-Russia on 2 March, Brussels, 2 March 2015, https://ec.europa. eu/commission/presscorner/detail/en/STATEMENT_15_4533.

European Council. Iran: Council Adopts Conclusions, 4 February 2019.

Fabius, Laurent. 'Inside the Iran Deal: A French Perspective', The Washington Quarterly, vol. 39, no. 3 (2016), pp. 7-38.

Fitzpatrick, Mark. 'Assessing the JCPOA', Adelphi Series, vol. 57 (2019), pp. 19-6o.

Grevi, Giovanni, Pol Morillas, Eduard Soler i Lecha and Marco Zeiss. 'Differentiated Cooperation in European Foreign Policy: The Challenge of Coherence', EU IDEA Policy Papers, no. 5 (August 2020), https://euidea.eu/wp-content/uploads/2020/o8/ euidea_pp_5.pdf.

Harnisch, Sebastian. 'Minilateral Cooperation and Transatlantic Coalition-Building', European Security, vol. 16, no. 1 (2007), pp. 61-77.

Haug, Hilde. 'The Minsk Agreements and the osce Special Monitoring Mission. Providing Effective Monitoring for the Ceasefire Regime', Security and Human Rights, vol. 27, no. 3-4 (2016), pp. 342-357, https://doi.org/10.1163/18750230-02703004.

Haukkala, Hiski. 'A Perfect Storm; Or What Went Wrong and What Went Right for the EU in Ukraine', Europe-Asia Studies, vol. 68, no. 4 (2016), pp. 653-664.

Helwig, Niklas. 'Germany in European Diplomacy: Minilateralism as a Tool for Leadership', German Politics, vol. 29, no. 1 (2020), pp. 25-41.

Howorth, Jolyon. 'Differentiation in Security and Defence Policy', Comparative European Politics, vol. 17, no. 2 (2019), pp. 261-277.

International Crisis Group. How Europe Can Save the Iran Nuclear Deal, Report 185, 2 May 2018.

International Crisis Group. The Iran Nuclear Deal at Four: A Requiem?, Report 210, 16 January $202 \mathrm{O}$.

International Crisis Group. Iran: The U.S. Brings Maximum Pressure to the UN, Report 218, 19 August 2020.

Kanet, Roger E. 'Russian Strategic Culture, Domestic Politics and Cold War 2.0', European Politics and Society, vol. 20, no. 2 (2019), pp. 190-206.

Kile, Shannon N. 'Final Thoughts on Iran, the EU and the Limits of Conditionality'. In Europe and Iran. Perspectives on Non-Proliferation, ed. S. N. Kile (Oxford: OuP, 2005), pp. 122-135.

Lavenex, Sandra and Ivo Križić. 'Conceptualising Differentiated Integration: Governance, Effectiveness and Legitimacy', EU IDEA Research Papers, no. 2 (November 2019), https://euidea.eu/wp-content/uploads/2019/12/euidea_rp_2.pdf. 
Mogherini, Federica 'The Iran Agreement Is a Disaster for Isis'. The Guardian, 28July 2015 , www.theguardian.com/commentisfree/2015/jul/28/iran-agreement-isis-vienna-eu.

Naim, Moises. 'Minilateralism: The Magic Number to Get Real International Action', Foreign Policy, no. 173 (2009), pp. 136-137.

Natorski, Michal and Karolina Pomorska. 'Trust and Decision-making in Times of Crisis: The EU's Response to the Events in Ukraine', Journal of Common Market Studies, vol. 55, no. 1 (2016), pp. 54-70.

Reuters. 'Italy PM Renzi Says Russian Sanctions to Be Reviewed in Coming Months', 16 December 2015, www.reuters.com/article/us-russia-eu-sanctions-italyidUSKBNoTZoUQ20151216.

Reuters. 'Germany's Steinmeier Favors Gradual Phasing-Out of Russia Sanctions', 19 June 2016, www.reuters.com/article/us-ukraine-crisis-germany-steinmeieridUSKCNoZ5oAI.

Siddi, Marco. 'German Foreign Policy towards Russia in the Aftermath of the Ukraine Crisis: A New Ostpolitik?', Europe-Asia Studies, vol. 68, no. 4 (2016), pp. 665-677.

Siddi, Marco. 'A Contested Hegemon? Germany's Leadership in EU Relations with Russia', German Politics, vol. 29, no. 1 (2020), pp. 97-114.

Siddi, Marco. 'EU-Russia energy relations'. In Handbook of Energy Governance in Europe, eds Michèle Knodt and Jörg Kemmerzell (Cham: Springer, 2020), pp. 1-25. Sjursen, Helen. 'The legitimacy of European Union foreign policy', Global Affairs, vol. 4, no. 2-3 (2018), pp. 253-264.

Sus, Monika. 'Poland: Leading Critic or Marginalised Hawk?'. In EU Member States and Russia: National and European Debates in an Evolving International Environment, ed. Marco Siddi (Helsinki: Finnish Institute of International Affairs, 2018), pp. 77-89.

Thomas, Daniel. 'Still Punching below Its Weight? Coherence and Effectiveness in European Union Foreign Policy', Journal of Common Market Studies, vol. 50, no. 3 (2012), pp. 457-474.

UnIAN. 'Polish Foreign Minister: Minsk Deal Not to Be Implemented, Normandy Format Must be Expanded', 27 December 2016, https://www.unian.info/politics/1699822minsk-deal-on-donbas-not-to-be-fully-implemented-polish-foreign-minister.html.

Viceré, Maria Giulia Amadio. 'Looking towards the East: The High Representative's Role in EU Foreign Policy on Kosovo and Ukraine', European Security, vol. 29, no. 3 (2020), pp. 337-358.

Yoder, Jennifer. 'Dialogues, Trialogues and Triangles: The Geometry of Germany's Foreign Policy of Trust-Building', German Politics, vol. 26, no. 2 (2017), pp. 195-218. Wittke, Cindy. 'The Minsk Agreements: More Than 'Scraps of Paper'?', East European Politics, vol. 35, no. 3 (2019), pp. 264-29o. 